\title{
Anti-Semitism and Apostasy in Nineteenth-Century France: A Response to Jonathan Helfand
}

\author{
Todd M. Endelman
}

In "Passports and Piety: Apostasy in Nineteenth-Century France" (Jewish History, Fall 1988), Jonathan Helfand addresses one of the central issues in the study of the Jewish communities of the West in the modern period. In discussing the extent of conversion from Judaism to Christianity in France, he poses the question of whether Jews were able to participate in the mainstream of French society in the decades following emancipation without relinquishing their ties to the Jewish community. Recognizing the imperfect character of Jewish emancipation in France, that is, the failure of legislative action to eliminate social discrimination and religious prejudice, Helfand asks whether anti-Semitism remained so pervasive after the Revolution that it eroded Jewish loyalties and encouraged conversion to Christianity. In other words, was the situation in France similar to that in the German states before emancipation, when legal impediments to advancement led many ambitious and talented Jews to flee their Jewishness?

Helfand answers in the affirmative. As the title of his article suggests, he believes that the much-quoted aphorism of Heinrich Heine that baptism was "the entrance ticket to European culture" describes conditions in France as much as in Germany. He also believes that modern Jewish historiography has ignored conversion in France and that some historians have created a false impression of the situation by maintaining that apostasy was infrequent and uncharacteristic. His intention then is to offer "a revision of the prevailing view and its underlying presumptions." In his view, Jews were victims of discrimination in professional and public life throughout the nineteenth century, and, as a result, "during the first half of the nineteenth century there was a significant conversionist movement in France."1

Helfand's article joins a growing body of literature on the phenomenon of conversion in the modern period ${ }^{2}$ and is to be welcomed for casting the discussion 
in an even broader comparative context. Moreover, if his revisionist perspective is correct - which is to say, if anti-Semitism weighed as heavily on French Jews as it did on German Jews - then much of modern Jewish history will have to be rewritten, along with the political history of France, since the implication of Helfand's revisionism is that France and Germany were far more similar in terms of political culture and social environment than most historians have imagined. Clearly, there is more at stake here than the question of how many Jews converted to Christianity. To this reader, however, it does not seem likely that any such fundamental reconsideration will occur, for neither the evidence nor the logic of the article are adequate to support the larger claims being advanced. It is to a close examination of such matters that I now turn.

One question that must be resolved at the very outset is that of periodization. The title of the article suggests that the period under review is the nineteenth century, which, in the case of France, is usually understood as 1815 to 1914 . However, Helfand indicates at the start that he is confining his discussion to the first half of the nineteenth century, which in fact is what he does: no evidence is cited for any decade after the $1860 \mathrm{~s}$. (Most of his material is drawn from the $1820 \mathrm{~s}, 1830 \mathrm{~s}$, and 1840s.) This in itself is not a serious problem, although it would have been helpful if the title of the article accurately reflected its scope. The difficulty is that in making revisionist claims for his work Helfand sets his "discoveries" against the conclusions of historians and observers commenting on the extent of apostasy at the end of the century. When Simon Debré wrote in the Jewish Quarterly Review in 1891 that "apostasy from Judaism to Christianity is absolutely unknown," he was describing the situation in France at the time he was writing rather than in the first half of the century. Similarly, when Michael Marrus wrote in his study of the French Jewish community at the time of the Dreyfus affair that "relatively few [Jews] took the final step of renouncing their religion and converting to Christianity," he was referring to the Third Republic, not to the various regimes that preceded it. ${ }^{3}$ If Helfand wishes to cast himself in the role of historical revisionist, he needs to establish what the accepted view is with regard to the first rather than the latter part of the century.

The extent of conversion in France before the Third Republic is not, in fact, the unexplored question that Helfand's article seems to suggest it is. The problem attracted some scholarly attention in the 1970s and 1980s, in both France and the United States, and those who examined the evidence concluded, in contrast to Helfand, that there was little movement from Judaism to Christianity, certainly in comparison to the German states. Patrick Girard, for example, in a survey of French Jewry between 1789 and 1860 , wrote that due to the granting of legal equality "les conversions de Juifs en France ne prirent jamais le caractère épidémique qu'elles eurent en Allemagne de 1820 à 1848." In a study of the assimilation of Parisian Jewry between 1808 and 1840, Christine Piette came to a 
similar conclusion: relatively few families, certainly among the Ashkenazi majority, chose the path of complete assimilation through baptism into the Catholic faith. (Curiously, Helfand cites neither work, either in this or any other context.) And in a study of the Jews of Alsace in the decades before the Franco-Prussian war, Paula Hyman concludes that baptism was an exceptional occurrence there, with the rural, conservative social context in which Jews lived and their concentration in the region acting together as a brake on radical assimilation. ${ }^{4}$ It is the conclusions of historians such as these, rather than those whose work focuses on the end of the century, that Helfand seeks to dislodge.

A major obstacle to resolving the dispute over the extent of conversion is the absence of firm statistical evidence to support either perspective. In liberal states like France, Great Britain, and the United States, religious affiliation was not an aspect of civil status, so the state did not monitor formal shifts in religious identity as it did in central and eastern Europe. Consequently, it is impossible to know with any precision how many French Jews converted either on an annual basis or over an extended period. Any historian who writes on the subject ultimately must rely on impressionistic, anecdotal, non-quantitative evidence. When Helfand quotes the late Zosa Szajkowski to the effect that from the First Empire "the number of conversions ... became large, proportionately much larger than in neighboring Germany,"5 and then notes that Szajkowski did not live to undertake an intended essay on this subject, the implication is that a statistical comparison is possible. ${ }^{6}$ This is misleading, because the materials do not exist for such a comparison. Indeed, for the first half of the century the statistical evidence for even the German states is fragmentary and scattered.

The one attempt to establish the number of Jews who became Christians in nineteenth-century France - that of the German conversionist J. F. A. de le Roi, whose estimate Helfand cites without comment - is worthless. On the basis of missionary statistics (which are notoriously unreliable) and what can only be called statistical leaps of the imagination, de le Roi concluded that there were approximately 1,800 conversions to Christianity. De le Roi began with the number of conversions made by Protestant missionaries in the last forty years of the century, which totaled 104 (according to missionary sources), and then, for reasons not made clear, multiplied that number by six to arrive at the total number of converts to Protestantism for the entire century - that is, about 600 persons. This estimate, however, refers to both France and Algeria, since 36 of the 104 former Jews who constituted the statistical foundation for this estimate were converted under Protestant auspices in Algeria! To arrive at the number of persons converted to Catholicism, de le Roi doubled the number of those he calculated had converted to Protestantism, on the assumption that there were at least twice as many converts to the dominant religion. He thus concluded that there were about 1,800 Jewish converts to Christianity in France (and Algeria). ${ }^{8}$ Statistics such as these mean very little. 
However, despite the absence of statistical evidence, researchers need not throw up their hands in despair. Alternative ways of gauging the relative extent of conversions are available, although it must be acknowledged that they are crude and impressionistic. One such way of approaching the problem is to ask whether contemporaries noticed a disturbing rise in the number of baptisms and, if so, whether they attributed the increase to obstacles blocking the integration of ambitious Jews into the mainstream of society. Helfand apparently found little evidence of this kind. He quotes one report from the Archives israélites in 1854 linking the exclusion of Jews from the école professionelle of Toulouse with the apostasy of a Jewish musician. ${ }^{9}$ This does not suggest a broad consensus that the failure of emancipation had created an unprecedented wave of conversions. In fact, the only other testimony of this kind that Helfand includes suggests the very opposite. Perhaps without fully realizing its implications, he cites in another context the conclusion of the Protestant missionary A. E. Thompson that French Jews were so irreligious as to provide "barren soil for the seed of the Gospel," preferring assimilation to conversion. ${ }^{10}$ In other words, French Jews were so indifferent to religion that they could not be bothered to be baptized even after they had become alienated from Jewish practice and belief. (This was not a unique or eccentric view, it should be noted. Theodore Ratisbonne, one of the most famous converts of the early nineteenth century, reached the same conclusion. Writing in 1858 , he quipped, "Les Juifs ne sont plus Juifs, ils ne sont pas encore chrétiens."11) One must assume that if ambitious Jews felt their nominal attachment to Judaism was an obstacle to their successful integration they would have renounced it, since, after all, it had ceased to have much meaning for them - which was what happened in Germany from the time of Moses Mendelssohn on. ${ }^{12}$

There is one other way to establish the approximate extent of conversion in the absence of statistical data, and that is to identify as many instances of conversion as the available sources permit and then analyze this data, seeking to describe patterns and trends rather than measure precise shifts. This, for example, is the method employed by Christine Piette in her study of the Jews of Paris in the period 1808 to $1840 .{ }^{13}$ Helfand, however, adduces no more examples of conversion than Piette, although the scope of his research is broader, not being limited to Paris before 1840 .

More critical, perhaps, than the small number of cases identified by Helfand is the fact that the majority of those he does discuss are irrelevant to the revisionist argument he is making, that is, that substantial numbers of French Jews were baptized in order to surmount vocational and social barriers. In France in the period under discussion, there were, broadly speaking, three kinds of converts: (1) ambitious, highly gallicized, well-to-do Jews who converted for pragmatic reasons, that is, to obtain social or material advantages; (2) well-educated, emotionally adrift young men, alienated from Judaism and in search of spiritual fulfillment, who converted for sincere religious reasons and later sought to spread their new faith 
among their former coreligionists; and (3) poor, aged, incarcerated, infirm, or otherwise vulnerable Jews, who responded positively to missionary appeals because of the extreme circumstances in which they found themselves. ${ }^{14}$ The bulk of Helfand's discussion (approximately ten pages) is devoted to conversions from the second and third categories, while a mere two paragraphs (approximately half a page) are devoted to opportunistic conversions. Yet it is only this kind of apostasy that is relevant to his attempt to revise our understanding of French Jewish history in the nineteenth century.

Pious apostates like the Ratisbonne brothers, David Drach, and Francis Libermann embraced Christianity because it met their personal psychological and spiritual needs, not because it aided their social and vocational advancement. The role of anti-Semitism in their decision to become Christians was indirect and limited. It influenced them only in that Christian depreciation of Judaism made their inherited faith seem worthless and that the close identification between Christianity, on the one hand, and state, culture, and society, on the other, seemed to confine them, as Jews, to the margins of French life. ${ }^{15}$ To this extent, and only to this extent, did anti-Semitism contribute to their flight from Judaism.

As for the beggars, prisoners, orphans, abandoned children, mental patients, and servants who became Christians, it is clear that poverty and emotional distress, rather than social prejudice and occupational discrimination, were responsible for their abandonment of Judaism. Missionizing priests and nuns had no access to middle-class French Jews, and were able to make contact only with those members of the community who became dependent on non-Jewish institutions and individuals for one reason or another. In periods of financial and emotional distress, such persons became easy prey for conversionists offering psychological support and material relief. Although French Jewish leaders repeatedly expressed concern about missionary inroads and actively sought to counter conversionist propaganda, they never fully acknowledged that it was the inadequacy of communal institutions that forced the Jewish poor into circumstances in which they became vulnerable to proselytism. In any case, it is difficult to see the relevance of cases like these to Helfand's revisionist interpretation. In Victorian England, where Jews encountered less occupational and social discrimination than in other European states, missionaries were equally successful in their work among the Jewish poor. ${ }^{16}$

If the central issue is whether anti-Semitism promoted apostasy in France, then the discussion must focus on so-called pragmatic conversions. Unfortunately, with regard to such conversions, Helfand uncovers little that is new, devoting, as I have indicated, less than one page to them. Moreover, in his treatment of this pattern of defection, he fails to stress an important distinction necessary to understanding the relationship between anti-Semitism and apostasy. When university-educated German Jewish men converted, they did so because their Jewishness was a 
considerable barrier to extensive participation in prestigious areas of the larger society. Being Jewish blocked their entry into the judiciary, the diplomatic corps, the academy, the military, and the civil service; it burdened their social relations, preventing their integration into elite social circles and organizations and injecting a note of unpleasantness into routine contacts with neighbors, merchants, schoolmates, and state officials. When their counterparts in England converted, they did so primarily to complete a process of social integration that was already well underway and in many cases all but complete. (English Jews were content for the most part to remain in occupations in which there were no obstacles to mobility.) Conversion for them was not an entry ticket into a world from which they had previously been excluded but an acknowledgment of the distance they had already traveled. In the first instance, conversion was intended to gain entry into a society that tried to confine Jews to its margins; in the second, it was intended to obliterate the last remaining distinction between assimilated Jews and the society into which they had already been substantially incorporated. This is an important distinction.

In France in the period 1815-1870, conditions more closely resembled those in England than those in the German states. On the relatively few occasions when middle-class Jews converted for opportunistic reasons, it was rarely, as in Germany, in order to obtain a position in public service. ${ }^{17}$ Socially ambitious French Jews who converted were moved to do so not by their distance from the surrounding society but by their proximity to it and by their desire to avoid even the least hindrance to their complete social integration. It is no coincidence that a disproportionate number of those converting for pragmatic reasons in the first decades of the century were Sephardim. ${ }^{18}$ Already gallicized before the Revolution, they entered French society with ease in the years following their legal emancipation. ${ }^{19}$ Their formal abandonment of Judaism was thus a consequence of prior acculturation and integration.

With few exceptions, French Jews in the first half of the nineteenth century were able to satisfy their longing for material success and social respect without changing their religion. Although imperfect, emancipation swept away the most onerous legal restrictions of the old regime. Jews could live wherever they wanted and make a living in any manner they chose - which was sufficient for most. Because of this and because capitalism was held in greater esteem than in Germany, there was little flight from "Jewish" occupations (street-trading, retail and wholesale commerce, brokerage, finance) to the liberal professions; so few Jews were even in a position to encounter the kind of obstacles that faced a Heine or a Gans. Most Jews were content to become part of the commercial bourgeoisie, to enjoy the prosperity that was increasingly theirs, and to endure the occasional anti-Jewish hostility that came their way. The most convincing proof of this is the absence of significant Jewish migration from France in the nineteenth century. Between 1810 and 1910, more than 200,000 Jews left Germany to escape legal and social conditions that had 
become intolerable. ${ }^{20}$ If anti-Semitism was as much a barrier to social and economic mobility in France as it was in Germany - as Helfand maintains it was - then one would surely expect French Jews to have acted similarly and to have looked for a better life elsewhere. (The Alsatian Jews who sought their fortunes in the California gold rush of 1849 are the exception that proves the rule.) That so few French Jews chose to migrate abroad suggests that the parallels that Helfand is attempting to draw between France and Germany are weak and fail to enhance our understanding of the impact of anti-Semitism on nineteenth-century Jewish communities.

\section{NOTES}

I am grateful to Victor Lieberman and Deborah Hertz for their helpful comments on a draft version of this article.

1. Jonathan I. Helfand, "Passports and Piety: Apostasy in Nineteenth-Century France," Jewish History 3 (Fall 1988): 60.

2. See, for example, Marsha L. Rozenblit, The Jews of Vienna, 1876-1914: Assimilation and Identity (Albany, 1983); Todd M. Endelman, ed., Jewish Apostasy in the Modern World (New York, 1987); Deborah Hertz, Jewish High Society in Old Regime Berlin (New Haven, 1988); Peter Honigmann, Die Austritte aus der Jüdischen Gemeinde Berlin, 1873-1941 (Frankfurt, 1988); Todd M. Endelman, Radical Assimilation in English Jewish History (Bloomington, IN, 1990).

3. Simon Debré, "The Jews of France," Jewish Quarterly Review 3 (1891): 393; Michael R. Marnus, The Politics of Assimilation: A Study of the French Jewish Community at the Time of the Dreyfus Affair (Oxford, 1971).

4. Patrick Girard, Les Juifs de France de 1789 à 1860: de l'émancipation a l'égalité (Paris, 1976), 156; Christine Piette, Les Juifs de Paris (1808-1840): la marche vers l'assimilation (Quebec, 1983), 151; Paula Hyman, The Emancipation of the Jews of Alsace: Acculturation and Tradition in the Nineteenth Century (New Haven, forthcoming). In an endnote, Helfand implies that material in David Cohen, La Promotion des Juifs en France à l'époque du Second Empire (1852-1870), 2 vols. (Paris, 1980), 2:719-25, supports his thesis that conversion was a serious problem before the establishment of the Third Republic. It is difficult to see how the few examples presented by Cohen can be interpreted in this light.

5. Zosa Szajkowski, "Secular versus Religious Jeswish Life in France," in The Role of Religion in Modern Jewish History, ed. Jacob Katz (Cambridge, MA, 1974), 112.

6. Helfand, "Passports and Piety," 76 n. 8.

7. The evidence for studying apostasy in the German states before 1870 is discussed in Abraham Menes, "The Conversion Movement in Prussia during the First Half of the Nineteenth Century," YIVO Annual of Jewish Social Science 6 (1951): 190-91; Jacob Toury, Soziale und politische Geschichte der Juden in Deutschland, 1847-1871: zwischen Revolution, Reaktion und Emanzipation (Dusseldorf, 1977), 51-60; Deborah Hertz, "Seductive Conversion in Berlin, 1770-1809," in Jewish Apostasy in the Modern World, 50-54.

8. J. F. A. de le Roi, Judentaufen im 19. Jahrhundert: ein statistischer Versuch (Leipzig, 1899), 27, 39-40.

9. Helfand, "Passports and Piety," 61. Two years later, however, the Archives israélites spoke of "les rares abjurations juives qui se produisent en France," a phrase that does not suggest a community troubled by a plague of conversions. Les Archives israélites 17 (1856): 695, quoted in Girard, Les Juifs de France, 158. 
10. Helfand, "Passports and Piety," 69.

11. Theodore M. Ratisbonne, La question juive (Paris, 1858), 8, quoted in Girard, Les Juifs de France, 159.

12. See, for example, the evidence in Todd M. Endelman, "The Social and Political Context of Conversion in Germany and England, 1870-1914," in Jewish Apostasy in the Modern World, 88-93; idem, "Conversion as a Response to Antisemitism in Modern Jewish History," in Living with Antisemitism: Modern Jewish Responses, ed. Jehudah Reinharz (Hanover, NH, 1987), 67-75.

13. Piette, Les Juifs de Paris, 150-55.

14. These are not hard-and-fast categories, of course. Some wealthy persons converting for social reasons might have justified their decision in religious terms. Doing so would certainly have made them feel better about their decision. In addition, there undoubtedly were some converts who were motivated equally by spiritual and pragmatic concerns. Such persons, however, should not be grouped together with those in the second category, for whom religious issues were paramount, as evidenced by the fact that after their conversion they devoted themselves to the evangelization of their former brethren.

15. See the excellent discussion of this point in Jacob Katz, "Religion as a Uniting and Dividing Force in Modern Jewish History," in The Role of Religion in Modern Jewish History, 7-8.

16. Endelman, Radical Assimilation in English Jewish History, chap. 5.

17. Piette, Les Juifs de Paris, 152.

18. Ibid., 155. In his discussion of conversion, Helfand lumps together all Jews living within the boundaries of the French state, regardless of their immediate historical experience in the period before the Revolution. Given the differences in levels of acculturation, integration, and secularization between the Sephardim and Ashkenazim, it would have been more useful to treat the two groups separately.

19. Frances Malino, The Sephardic Jews of Bordeaux: Assimilation and Emancipation in Revolutionary and Napoleonic France (University, AL, 1978), 57-58.

20. Avraham Barkai, "German-Jewish Migrations in the Nineteenth Century, 1830-1910," Leo Baeck Institute Year Book 30 (1985): 310.

\section{University of Michigan}

